\title{
Poles apart? A comparative study of housing policies and outcomes in Portugal and Denmark
}

Remarkable differences in housing policies and dominant forms of tenure can be observed across countries. To what extent are these differences dictated by major vested interests, and explained by ideology in the context of broader political and socioeconomic circumstances? Assuming that the comparison between northern and southern European countries has been largely neglected in comparative housing literature, by using the Danish and Portuguese cases I test Kemeny's typology of rental systems to explain the divergence between these two housing realities. The empirical evidence presented in this paper emphasizes the relevance of Kemeny's theories in explaining many of the divergent features of these housing systems, but suggests some adjustments, based upon the differences between Kemeny's theories of dualist rental systems and what was found in the Portuguese case, which aim to expand its explanatory power.

Keywords: ideologies, housing systems, Portugal, Denmark, dualist rental markets.

\section{Introduction - On the relationship between political ideologies and housing systems}

Whilst housing is a critical component of human well-being and is often an individual's single largest expense (Schwartz 2012), the role of the state in housing markets varies significantly across countries, not only in terms of "how much state involvement there is" (the level of government intervention), but also "what form it takes" (the nature of intervention within this field) (Kemeny 2001, 66).

The relative position of housing within systems of welfare when compared to other domains of social policy (social security, health, and education), has been explained not only by the fact that housing represents a capital-intensive investment, but also because it is a marketable good with a strong potential to generate capital gains, which in turn generates major pressures regarding the policy of state support. 
In the comparative international research on housing and welfare regimes, ideologies have been identified as a crucial factor to explain the way national systems are constituted, sustained, and change over time (Ball et al. 1988; Kemeny 1992). As Oxley and Haffner (2012) point out: "contrary to the structural determinism of the convergence approaches, the so-called divergence approaches assume that countries have a choice within the same stage of economic development" (idem: 203). For example, they can choose to support non-profit providers of rented housing that are in competition with for-profit providers, or promote a (marginalized) public rental sector only for the poor.

In the field of cross-national housing research, the relevance of political ideologies, what King (2012) defines as "a set of political beliefs about how society ought to be and how to improve it", has been emphasized since it is evident that these are "complex and dynamic formations" (Cash 1996, 3) that provide the motivation for action and can channel such action into the creation or legitimization of various mixes of state intervention (Kemeny 2001).

The relationship between ideology and state intervention is analysed by SkifterAndersen (2012) who distinguishes three types of ideology regarding the appropriate level of state intervention in housing. The first sees housing primarily as a private form of consumer good and state intervention is necessary only in extreme situations. The second understands housing policy as a domain to support those groups that are unable to achieve acceptable housing conditions by themselves. The third perspective underlines the importance of housing for the well-being of individuals and families, therefore supports state intervention to ensure a good supply of housing for all social groups (Skifter-Andersen, 2012).

Whereas access to affordable housing of a good quality is considered a fundamental right in many countries, very few have supported a large and high quality stock of nonprofit rental housing, whilst in others, where liberal ideology dominates, the advantages of the free market and of private ownership have been supported often at the expense of social housing, which is restricted, via rigorous targeting, to households in need (King 2012). 
In the ideological debate on housing, Malpass and Murie (1998) distinguish broad differences between the 'left' and the 'right'. On the left, there is the view that housing problems stem from the fundamental inability of market mechanisms to deliver satisfactory accommodation in sufficient amounts to satisfy basic needs. On the right, there is the view that state intervention is a cause of housing problems rather than their solution (Malpass and Murie 1998).

In the debate on typologies of welfare regime and housing system, ideology has been used to explain similarities and differences between groups of countries, but it has also acknowledged that countries which adhere to the same welfare regime, therefore share many socio-economic, political, and ideological similarities, can develop different housing systems in terms of politics, institutions, and markets. An expressive example of this are the five Nordic countries which, whilst belonging to the social democratic regime, that is, characterized by high levels of de-commodification ${ }^{1}$ and well-funded welfare benefits and social services (Alves 2015), and an ideology that supports a good supply of housing for all social groups, have nevertheless developed various structures of housing provision, in terms of institutions involved in the provision of particular forms of housing, or instruments and measures chosen to achieve their goals ${ }^{2}$ (Bengtsson and Ruonavaara 2011). As a consequence, as Kemeny (2006) points out, the Nordic countries do not comprise a uniform category as regards rental housing: "in terms of the two-fold rental housing systems outlined above, Sweden and Denmark have integrated rental markets, whereas Finland and Norway have dualist rental systems" (idem: 6).

These differences have been explained on the basis of path-dependency theories, which claim that earlier policy decisions (in terms of policies or institutional arrangements) set welfare states on distinct policy trajectories that are afterwards difficult to reverse

1 'De-commodification' refers to the extent to which a regime promotes an acceptable standard of living independently of market participation, therefore without reliance upon income earned in the market sphere (Alves, 2015).

2 For example, whereas housing policies in Denmark, Sweden, and Norway can be characterized as universal (i.e. they do not target any specific income group), they are selective in Finland and Iceland, focusing upon households of lesser means. Also, whilst housing policies in Denmark and Sweden have focused upon rental housing, in Norway housing policy has been framed around individual and cooperative ownership (Smas et al. 2013, 15). 
(Lujanen 2004; Bengtsson and Ruonavaara 2011). In the debate over the issue of permanence versus change within a country or group of countries over time, it has been emphasized that, on the one hand, the housing stock, which is generated over several decades, sometimes hundreds of years, is a: "powerful historical heritage that any government has to deal with when making housing policy decisions" (Bengtsson and Ruonavaara 2010,193). On the other hand, processes of gradual or incremental change have been observed in many countries (cf. Malpass, 2011; Andersen and Winther 2010).

\section{Kemeny's theories of rental housing markets}

“Kemeny's interest in ownership forms was awakened in 1972 when he, an Englishman, arrived in Sweden. He was surprised to note that so few Swedes seemed to be interested in homeownership, regarding rented accommodation as a viable long-term prospect." (Elsinga and Hoekstra 2005, 405)

Trying to overcome the limitations of empiricist approaches that tend to merely juxtapose the particularities of countries, and of convergence approaches that tend to relegate differences between countries to the status of 'variations' or 'exceptions' (Kemeny and Lowe 1998, 162), Kemeny developed a theory which seeks to explain the divergence between rental systems across countries ${ }^{3}$.

Kemeny, who considers Esping-Andersen's typology of welfare regimes (1990) a useful theoretical anchor to explain the nature of welfare provision across countries, claims that ideologies are based upon and derived from power and inter-class alliances (Kemeny 2001, 59), and in turn influence the degree of privatization in society. Kemeny claims that the privatization of housing consumption through owner-occupation acts as a powerful force to maintain or increase privatization in other spheres of life. (Kemeny 2006). Why one type of welfare regime and housing system is developed by a particular group of countries whereas an alternative type develops in another group of countries is the object of this research.

\footnotetext{
3 Cf. "why homeownership is regarded as the norm for the British middle class, while rented accommodation forms a perfectly acceptable alternative for most Swedes" (Elsinga and Hoekstra 2005, 405).
} 
Following Esping-Andersen (1990), Kemeny observes that the social democratic regime, as an outcome of working-class movements and class- alliances that have isolated conservative forces, has led to universal and high levels of de-commodification in access to social resources. Kemeny also argues that the liberal regime type, as a result of the dominance of conservative forces and market imperatives, has led to low levels of de-commodification that are means-tested, while in the corporatist regime, with its intermediate level of de-commodification, different parties develop their own welfare sub-system (Kemeny 2001). Alternatively, it is possible to argue that conservative forces are more characteristic of corporatist welfare state regimes than liberal welfare state regimes, hence they are characterized by a combination of high insider employment rights and sub-systems of protection and rights that are based upon class and status (O'Connor 1993).

By distinguishing ideologies of 'privatism' versus 'collectivism', Kemeny identifies two main and opposing philosophies regarding the long-term structuration of rental markets and distinguishes between two rental systems - the integrated versus the dualist rental system.

"In one philosophy, the state takes upon itself the direct responsibility of providing rental housing in need. To this end, non-profit rental housing is organised in the form of a state or local government monopoly. [...]

In the other philosophy, the state is either not a major provider itself, or if it is, access to such housing - often provided on a non-for-profit basis - is not limited to households in need. Instead it is encouraged to compete with profit-rental housing on the open market for tenants and thereby sets standards, ensuring that all households have security of tenure and competitively holds rents down.” (Kemeny 2001, 66).

Whereas in the 'integrated' rental system the social (non-profit) and the private (forprofit) markets are incorporated into a single rental market; in the 'dualist' rental system these are strictly separated. As Balchin (1996) points out: "the state controls and residualises the social-rented sector to protect profit" (idem: 15). The United Kingdom (UK), Ireland, and Australia are examples of dualist rental systems.

Kemeny describes the integrated rental system as a 'social market model', in which: "the state encourages cost rental housing to compete directly with the private-rental sector in order to dampen rents and to provide good- quality housing on secure tenancy terms" (Kemeny 2006, 2). The model was inspired by the German ordo-liberals (see 
Kemeny 2006: 4) and developed in the neighbouring social democratic and corporatist countries of Sweden, the Netherlands, Germany, Switzerland, and Austria (Kemeny 1995). Kemeny (1995) describes the model as "a third way between two extremes of capitalism (liberalism) and communism", one that "would neither be subservient to the market nor try to determinate and dominate it", but rather would try to find a third direction - "an intervention for adjustment." (idem: 16).

Whilst Kemeny's theory focuses upon the rental markets, he claims that the way these are organized affects not only their conditions (cf. in terms of rent levels, housing quality, and so on), but also the development of the owner-occupancy sector. Kemeny predicts that, because the non-profit sector is limited to low-income families in the dualist rental system, the great majority of households will have to choose between, on the one hand, insecure and high rent profit renting and, on the other, owner-occupancy (Kemeny 1995), which would lead to the expansion of an equivalent sector.

An exploratory empirical test of Kemeny's theories was developed by Hoekstra (2009), who translates Kemeny's typology of rental systems into five hypotheses concerning measurable housing outcomes, such as housing quality, rent levels, and the income distribution of tenants. These hypotheses were tested for six countries - three presumed dualist rental systems (UK, Ireland, and Belgium) and three presumed unitary rental systems (the Netherlands, Denmark, and Austria) against data from the European Community Household Panel. Based on this empirical research, Hoekstra (2009) claims that Kemeny's typology of rental systems is a good predictor of measurable housing outcomes between countries that develop different rental systems.

\section{Purpose and hypotheses}

The aim of this paper is to test Kemeny's typology of rental systems $(1995,2006)$ on a bi-country comparison of housing systems that belong to different welfare state regimes - Portugal and Denmark.

To guide this comparative housing research, and to lend orientation to the rest of the paper, three hypotheses are formulated, as follows: 
1. In the context of broader political and socio-economic circumstances, ideology plays a crucial role in explaining differences between housing strategies and outcomes in both countries.

2. The Danish case is an example of an integrated rental system in which non-profit and for-profit markets are about equally balanced in terms of size, rent levels, housing quality, and tenants.

3. The Portuguese case is an example of a dualist rental system in which owneroccupancy is the dominant mode of tenure, the rental sector is minor, and the private and social rental markets are strictly separated. The social housing sector is residual and reserved for low-income families, while in terms of contract dates, rent values, and housing conditions, the private rental sector is composed of two sub-sectors.

The rationale for case selection and the methods are discussed below.

\section{Country selection and methods}

The selection of methods and countries for this comparative cross-country analysis was shaped by several factors. First, it became clear that the purpose of providing a comparative and comprehensive discussion of contrasting housing systems would require a restricted number of countries and the use of both quantitative and qualitative methods. Therefore, the analysis of macro-statistical data (collected from the national statistical services of countries selected) was complemented with a qualitative analysis (literature reviews and a small number of face-to-face interviews ${ }^{4}$ ) that would enable further scrutiny of the relationship between ideologies, housing policies, and outcomes in each country.

Second, Portugal and Denmark were selected because large differences between these countries make this comparison worthwhile. On the one hand, these two countries lie at extremes of a spectrum of welfare regimes which had different starting points, and have had different trajectories and levels of welfare development over time (Alves 2015). Whilst Denmark adheres to a social democratic regime in which social rights are

\footnotetext{
4 Ten interviews were conducted in 2014 with officials and academics who have been involved in policy-making, implementation, or evaluation of housing policies in the cities of Lisbon, Porto, and Copenhagen.
} 
universal and de-commodified, providing high standards of welfare for all (Alves 2015, 4), Portugal adheres to a Mediterranean regime characterized by rudimentary and ramified state intervention (Alves 2015). In regard to housing, whilst the Danish housing system evinces a more proportional balance among housing tenures, not only between rental and ownership but also between profit and non-profit forms of rental housing, in Portugal owner-occupancy is by far the dominant tenure (Alves and Andersen 2015).

Third, comparison of the Nordic and Southern European countries has been largely neglected in international comparative housing research. Whilst including other Mediterranean EU countries, the pioneering work of Allen et al. (2004) only marginally considered the Portuguese case. In addition, comparative work by Hansen and Silva (2000) and, more recently, Alves (2015) on the Portuguese and Danish welfare systems, and patterns of social and economic change from the mid 1980s until the financial crisis of 2008, have totally neglected housing as a social field of analysis. As pointed out by Oxley and Haffner (2012, 201), like other southern European countries, Portugal "has been the subject of relatively few studies" of comparative housing research, which justifies the significance of the present contribution.

\section{Housing policies and outcomes in comparative perspective}

Several authors (Ruonavaara 1993; Stams $\varnothing$ 2010; Ball et al. 1988) have observed that cross-national comparison of housing policies and outcomes is difficult for several reasons. Besides discussing the complexities of varying institutional and cultural settings, Oxley (2001) points out that "differences in definitions, data recording and the very nature of the item one is trying to quantify" make comparing data problematic (idem: 101). Not only do concepts and housing indicators mean different things in different countries, but also the financial arrangements under which different types of housing are provided are not the same everywhere. On this issue, Stams $\varnothing$ (2010) observes that indirect subsidies (such as rent regulation, interest subsidies, and revenue lost via tax subsidies) are generally more substantial than direct subsidies (such as housing allowances, housing grants, and loans), but they are not so easily monitored or do not appear in national accounts (idem: 68). Ball et al. (1988) and Ruonavaara (1993) 
claim that housing tenures are broad ideal categories that do not by themselves delimit a way of providing housing (Ball et al. 1988; Ruonavaara 1993). For example, subsidized housing can be provided through different housing tenures (of which housing cooperatives are one example) and forms of non-profit rental can be provided by private or public landlords (cf. housing associations or government bodies).

Given this reasoning, to designate housing in which rents and allocation criteria are not set by market criteria, I use both the concepts of 'private non-profit' for the case of Denmark and of 'social housing' for the case of Portugal. The decision to use both concepts rather than a catch-all concept such as 'public housing' or 'social housing' is justified by the legal nature of the providers, that is, private without the purpose of generating profit in Denmark, public in the case of Portugal, and the rent regime. Whilst in the case of Portugal rents are defined by social principles and household income, in Denmark they are defined by the cost of building and operating housing units, with local authorities providing housing allowances to tenants who cannot afford them (Alves and Andersen 2015).

Apart from the gap between different statistical and analytical concepts and definitions across countries, changes in the conditions of the same tenure over time (cf. property rights or the role of the tenure in relation to other tenures), can make comparisons difficult. A striking example is the case of housing cooperatives. In housing cooperatives a dwelling can be owned under different schemes - e.g. sometimes only the dwelling is privately owned, while the building is owned jointly by a group of people (Skifter-Andersen 2012, 23); whereas in others the property rights are fully owned by individual members (Alves 2015). The role of housing co-operatives has also changed over time. This occurred in the cases of housing co-operatives in both Portugal and Denmark ${ }^{5}$, where the increased 'marketization' of the sector over recent decades has justified the sector's inclusion, for statistical purposes, in the home- ownership type of tenure (Norris and Winston 2012, 131). On this issue, Skifter-Andersen (2012) notes that in Denmark not only has the price of co-operatives increased to the same level as home- ownership in recent years, but access to co-operative dwellings is also strongly conditioned by social relations (idem: 23).

5 According to Norris and Winston (2012), the co-operative housing sector represents, respectively, $1 \%$ and $6 \%$ of the total housing stock. 
The remainder of this paper is structured as follows. The next section presents an up-todate and comparative empirical analysis of the housing structure in Portugal and Denmark, in which general economic and demographic data is presented for these countries. The empirical element is then split into two parts. The first uses a historical perspective to trace and explain the development of housing policy in both countries. This exercise is carried out, as far as possible, from a comparative perspective, with the aim of identifying and discussing the main normative ideas and socio-economic and historical conditions that have shaped the long-term structuration of housing systems in Portugal and Denmark. The second element employs quantitative data analyses of the characteristics of different housing tenures (cf. rent values, housing quality, affordability, household income characteristics), in order to identify the similarities and differences between what is predicted by Kemeny's theories on integrated and dualist rental systems and what is observed in Portugal and Denmark.

\section{General data on housing tenures}

Whilst the expansion of new housing and home- ownership is linked to periods of economic prosperity, the percentage of home- ownership does not reflect a country's relative prosperity (Kemeny 2006, 1). Salient examples of this are Portugal and Denmark. Whilst the area and demographic size of Denmark is about half that of Portugal, levels of Danish GDP are more than double the Portuguese figures (Table 1), whereas the share of home- ownership is less. Whilst in Denmark in 2013, 58\% of all persons lived in a privately owned dwelling (Skifter-Andersen (2014, 103), this proportion being relatively stable since 1981 (Statistics Denmark 2013), in Portugal this share raises to $73 \%$ (INE, Statistics of Portugal, 2012).

Table 1 about here. Table 1 - General data on demographic and socio-economic context and housing; Source: Dol and Haffner (2010); Pittini and Laino (2011); Statistics Denmark (2013).

Figure 1 depicts a dualist rental market system in Portugal characterized by the pronounced rise of home-ownership and a limited social and private rental sector which represents $3 \%$ and $20 \%$ of all housing stock respectively (see also Table 2). Figure 2 depicts an integrated model in the case of Denmark in which the rental and owneroccupancy markets are equally balanced. 
Figure 1 about here. Figure 1 - Distribution of population by tenure status: Portugal from 1960 to 2011; Source: INE (2012).

Table 2 about here. Table 2 - Tenure structure of housing markets (in percentage of total dwelling stock); Source: Skifter-Andersen (2014, 103); INE (2012).

Figure 2 about here. Figure 2 - Distribution of population by tenure status: Denmark from 1960 to 2011; Source: Statistics Denmark (2013)

Whilst the Danish process of industrialization and urbanization began in the early 19th century, and the process of housing expansion occurred from 1919 to 1970 (Figure 3), in the 1970s Portugal still presented one of the lowest levels of urbanization in Western Europe (only $27 \%$ of Portugal's population lived in urban areas) and $44 \%$ of the total active population still worked in the primary economic sector (Alves 2015).

Figure 3 about here. Figure 3 - Age distribution of housing stock in Portugal and Denmark; Source: Statistics Denmark (2013); INE (2012).

The process of urbanization that evolved from the mid 1970s with the creation of new jobs in the cities led to a boom in housing construction after the entry of Portugal into the European Union in 1986 (Alves, 2015). Analysis of the housing stock by date of construction shows that about $18 \%$ of the buildings were built after 1960 and $30 \%$ were built during the period 1990-2011 (Figure 3).

Table 1 demonstrates that Portugal has a higher number of dwellings per 1,000 inhabitants than Denmark (557 and 500, respectively) and, moreover, a greater number of dwellings that are not used permanently. Data on the latter shows that the proportion of vacant dwellings in Portugal is twice that of Denmark, equivalent to $13 \%$ of the total housing stock in 2011 - i.e. 735,000 vacant housing units, ${ }^{6}$ while in Denmark in 2009 it was $7 \%$ of the housing stock (Dol and Haffner 2010).

\footnotetext{
$6 \quad$ We should also note that, of the total number of vacant houses in Portugal only $34 \%$ were available for purchase or rent, while the remaining $66 \%$ were not available for purchase or rent owing to high levels of deterioration, a situation that is predominant in buildings constructed before 1919, that is, those in the largest city centres.
} 
Second homes, that is, houses that are owned or rented for the purpose of temporary residence (during weekends or holidays) ${ }^{7}$ are also three times more common in Portugal than in Denmark. Whilst in Portugal the stock of second homes represents $23 \%$ of all dwellings, i.e. 1,133,300 homes (INE 2012), in Denmark it represents $8 \%$ of all dwellings - i.e. 220,000 in 2007 (Tress 2007). Whereas in Denmark second-home expansion was rigidly controlled - among other restrictions, the use of second homes was prohibited for purposes other than recreation (to avoid urban sprawl) and the purchase of second homes by foreigners was also prohibited (Tress 2007), in Portugal decisions at the land-use planning level were not guided by environmental concerns, but mainly served the interests of construction that sought to address a demand for summer houses, both native and foreign ${ }^{8}$. As a result of an instrumental use of land-use planning oriented towards market interests rather than to tackle trends of urban sprawl, and of pressures related to second homes and tourism, issues of affordability and effective local demand have become significant in Portugal (Carmo et al. 2014).

\section{Housing Policy in Portugal and Denmark}

Housing policies are defined by Skifter-Andersen (2012) as: "public initiatives that affect the supply, price and quality of dwellings, together with how they are distributed between households" (idem: 104). Elsinga and Hoekstra (2005) observe that housing policy influences both the development and the attractiveness of housing tenures (Elsinga and Hoekstra, 2005), while Bengtsson (2015) writes that tenure policy at the national level defines the evolution of housing politics at lower levels ${ }^{9}$.

\footnotetext{
7 They are typically built near the sea, but can also be located in rural areas, and in some cases might have functioned as permanent houses before the rural exodus.

8 On this issue, it is important to note that in some coastal regions, such as in the Algarve, summer houses today represent almost $40 \%$ of the total housing stock. This has had very adverse effects, including an intense environmental transformation of these areas (with the loss of ecological assets), and high costs associated with the provision of services and infrastructure in territories that are only seasonally occupied.

$9 \quad$ "Decision-making on tenure forms and other types of market regulations define the bargaining room for seller and buyer, landlord and tenant, together with economic support to different types of housing in terms of subsidization, financial security or tax relief." (Bengtsson 2015, 681).
} 
The analysis of government expenditure on housing and its desegregation according to main functions/goals or tenure forms enables us to grasp how governments deal with the tension between the idea of housing as a commodity, distributed by the market and/or the family, and as a right that should be protected by the state (Dewilde and Decker 2015, 8).

Depending upon historical factors and ideological preferences for 'privatism' versus 'collectivism' or for tenures (e.g. the provision of mortgaged home ownership allocated through the market, for rental allocated through non-profit housing companies and so on) levels of government involvement in the housing market vary significantly across countries (Dewilde and Decker 2015).

Figure 4 shows the comparative analysis of welfare spending on social protection from 2007 to 2014 in Portugal and Denmark. The results show that in 2014 government expenditure ${ }^{10}$ in both Denmark and Portugal accounted for more than half of GDP, 56\% and $52 \%$ of gross domestic product respectively. Whist Portugal has caught up with the relative values of social spending, in absolute terms it spends much less than Denmark owing to lower levels of Portuguese GDP. In this regard, it is useful to note that the catch up on government expenditure that followed Portuguese accession to the European Union in 1986 until the economic and banking crises of 2008 were associated with investment in the construction of infrastructure (cf. health, education) that have had positive effects on several aspects of living conditions among the Portuguese population (see Alves, 2015).

Figure 4 about here. Figure 4 - Total general government expenditure as a percentage of gross domestic product (GDP) 2007-2014; Source: Eurostat (2015)

Levels of spending in housing have been quite different in Portugal and Denmark, both in absolute and relative terms. Whilst intervention in housing makes up an important part of government expenditure in Denmark, in Portugal this is a very weak pillar of the welfare state when compared to other welfare sectors (e.g. education, health). Hence it

10 The Classification of the Functions of Government are usually classified into 10 main divisions (e.g.: general public services; defence; public order and safety; economic affairs; environmental protection; health; recreation, culture and religion; education; social protection, and housing and community affairs). 
cannot be recognized in Figure 5. In 2010 2\% of government expenditure in Denmark was devoted to housing, whilst the comparable figure for Portugal was $0.47 \%$. In absolute terms, these represented in the case of Denmark 13 billion DKK (1.7 billion euros) and in Portugal government expenditure in 2014 was 174 million euros.

Figure 5 about here. Figure 5 - Total social expenditure on housing in Portugal and Denmark 2012; Source: Statistics Denmark (2013); INE (2012).

Figures on government spending on housing between 1996 and 2010 (Figure 6) show that levels of state expenditure have steadily increased in Denmark while, after an increase until 2002, in Portugal levels fell by 2010 to just half of the spending registered in 1990.

Figure 6 about here. Figure 6 -Total government expenditure on housing in Portugal (in euros) and Denmark (DKK) 1996-2010; Source: Statistics Denmark (2013); INE (2012).

To make a distinction between the normative ideas and socio-economic and historical conditions that have shaped the long-term composition of the Portuguese and Danish housing systems, in this section I present a revision of the main housing policies, market, and family dynamics that contribute to explaining the distribution of tenures developed in Portugal and Denmark in recent decades.

\section{The non-profit rental sector in Denmark and the social housing sector in Portugal}

Identifying the proportion of social housing and/or non-profit housing within the rental sector is a way of measuring the extent to which housing is de-commodified or subsidized (Harloe 1995). In Portugal there are about 120,000 social housing dwellings, representing $3.3 \%$ of the total stock of permanent residences. In Denmark the stock of non-profit housing is six times bigger, equivalent to $21 \%$ of total housing stock.

The rationale and modes of organization in the social housing sector differ considerably in Portugal and Denmark. In Portugal social rented dwellings are generally owned and managed by municipalities or by municipal housing organizations, while a small share of this housing stock (equivalent to 12,550 dwellings in 2007) is also owned by the 
Institute of Housing and Urban Renewal (IHRU), a government-run body responsible for supporting and implementing government policy in the domain of housing (IHRU,2015).

In Portugal access to social housing is means-tested, which means that the public sector is restricted to the less well-off but this is so minor (3\%) that a considerable percentage of poor families in Portugal who cannot find accommodation in the social housing sector occupy the least attractive parts of the private rental housing market and the owner-occupancy sector. In this regard, it is worth noting that, after taxes and transfers, in 2014 around $28 \%$ of the Portuguese population was at risk of poverty whilst in Denmark this share represented $17.8 \%$.

Whilst the statistical data provided by Statistics Portugal (INE 2012), based upon information given by the municipalities, reports an overall positive balance between income and expenses associated with social housing, it does not include the cost of construction, housing management, or housing renovation. The average rent of a social housing dwelling in Portugal was 60 euros per month in 2012 (INE 2013). In the case of contracts with the IHRU as landlord, the average monthly national rent is 30 euros, but with significant regional variations ${ }^{11}$. It should be noted that the minimum wage in Portugal was set at 618 euros/month in 2014, while the average nominal monthly wage was in the same year equivalent to 1142.59 euros (Eurostat 2015). In 2011 when the annual average unemployment rate peaked at 12.9\% (Alves 2015), the number of rent arrears in the social housing sector reached 29,600 unpaid rents (INE 2012).

Considering that there is a lot of literature in English on the Danish case but the analysis of the Portuguese case is still relatively underdeveloped, I opt in this section to further extend the analysis of the Portuguese case.

\section{The social housing sector in Portugal}

Regarding the aims, beneficiaries, and models of production, four main periods can be identified in the history of social housing in Portugal: The 'Estado Novo Regime' [1933-74]; The 'Carnation Revolution' in 1974; The Special Rehousing Programme

\footnotetext{
11 In Lisbon, where the Institute owns about 2,600 dwellings, it is 76 euros per month, while in Porto where the IHRU owns about 2,025 dwellings, it is 61 euros per month.
} 
(1993), and the stock transfer and alienation of public housing stock. The main features and ideological and socio-economic constraints of each of these periods are briefly analysed below.

\section{The Estado Novo Regime [1933-74]}

The corporatist dictatorship that ruled Portugal from 1933 to 1974 proclaimed ownership as the perfect tenure for achieving social stability, using the family as the primary responsible institution for its provision. Besides implementing rent freezing, the residual percentage of housing promoted by the regime was highly stratified according to pre-existing class levels in an effort to maintain or preserve their power. O Programa de Casas Económicas (1935 to 1965) underwrote the construction of detached houses with gardens for working class people with secure income who were the main supporters of the regime. The houses were paid for through monthly rents and over a period of 25 years, eventually becoming the valued property of the family. O Programa de Renda Económica (1959-1969) promoted the construction of new towns, aiming at the consolidation of the urban fabric in Lisbon and Porto, but the large majority of lowincome householders in Portugal were not able to afford these houses and turned to the illegal or self-built markets.

Widespread illegal construction expanded in the suburbs and in the inner cities, where overcrowded dwellings with a lack of basic amenities (electricity, sanitation, or piped water) represented very poor housing conditions for low-income households.

In 1966 there was an estimated housing shortage of 500,000 dwellings. This led to the creation, in 1969, of the Fundo de Fomento da Habitação (Housing Development Fund), an agency which supported the direct promotion of housing but also promoted the development of mono-functional housing projects which did not include public services, transportation, and other amenities. The initiative also promoted the segregation of social classes across the residential structure.

\section{The 'Carnation Revolution' in 1974}

The 'Carnation Revolution' of April 251974 was characterized by a large social movement campaigning for the right to health, education, and housing. In the 1970s a large percentage of permanent housing accommodation in Portugal still had no basic facilities, such as running water (47\%), bath or shower (32\%), sanitation (58\%), and sewers (60\% of total housing stock). The acute qualitative and quantitative housing 
shortage in big cities was reinforced by internal and international migration flows. On the one hand, a strong exodus from rural to coastal urban areas within Portugal, and on the other, the movement of hundreds of thousands of refugees and 'retornados' ('returnees') fleeing from liberation struggles in the former Portuguese colonies of Mozambique, Angola, and Guinea-Bissau. In Portugal several programmes supported by architects and other activists were created to support urban renewal but with limited results. In the 1980s very high housing deficits persisted in Portugal, namely in the larger cities, where weak state regulation of land-use transformation (both at central and local levels), led to the expansion of an informal housing market without reference to planning rules, planning permission, or minimum standards.

\section{The Special Rehousing Programme (1993).}

Launched in 1993, and implemented in the subsequent two decades, the Programa de Erradicação de Barracas (PER) was designed with the primary aim of eradicating slums that expanded in the metropolitan areas of Lisbon and Porto. A housing survey carried out in Lisbon in 1993 identified 833 shanty towns inhabited by 27,850 families and a total of 92,450 inhabitants (Hansen and Silva 2000, 74).

Between 1995 and 2002, this programme enabled large-volume construction of (lowcost) public housing, that is, about 50,000 housing units, often located in suburban or peripheral areas according to a model of large-scale rehousing that led to the rise of dense neighbourhoods lacking equipment and infrastructure, and the concentration of individuals with similar traits of vulnerability. This model not only created neighbourhoods characterized by physical and social homogeneity, but also deepened trends of social and spatial segregation across the city and processes of stigmatization. In recent decades, many of these housing estates have degenerated into problem areas (Alves, In press).

\section{Stock transfer and alienation of public housing stock}

Between 1980 and 2007, the IHRU reduced its housing stock from 39,197 to 12,549 units by transferring it to municipalities (42\%) and through sales to sitting tenants $(26 \%)$. The strategy to increase home-ownership among lower income households has also been followed by right and left wing municipalities alike in recent decades as a mechanism for reducing municipality debt and increasing revenue for housing rehabilitation. Whilst right wing municipalities advocated the benefits of reduced state 
intervention, public debt, and increased family responsibilities, municipalities dominated by left wing parties have emphasized 'the right to own a property' and that home-ownership represents an important safety net for poor households in periods of income loss owing to unemployment, long-term illness, retirement etc. During this period, the proportion of sales varied between municipalities. In the case of Lisbon, $25 \%$ of the total housing stockwas transferred to sitting tenants (representing 7,666 units). In total, council housing was reduced from 30,934 units in 2011 to 23,268 in 2015.

\section{The non-profit rental sector in Denmark}

In Denmark the non-profit sector, which is owned by non-profit housing associations, provides housing unrestricted by income limits (Jensen 1997). Whilst the housing associations formed by trade unions, employers, and philanthropic societies were initially linked to white collar and the more affluent working class (Harloe 1995, Kristensen 2007), following the Second World War, in a context of 'system-wide crisis' (Doling 2012, 600), housing became a key political issue directly connectted to the construction of the welfare state. The health problems associated with poor housing and sanitary conditions in the industrialized cities resulted in a wider conception of housing for all (Kristensen 2007, 32). Since then, non-profit and universal housing has been associated with the social democratic ideology in Scandinavia (Sørvoll 2009) and with policies related to universalist programmes.

As explained by Alves and Andersen (2015), the Danish non-profit sector is financed first of all by mortgages on market terms. Mortgages cover $88 \%$ of the construction costs (including land), the local government covers $10 \%$, and tenant deposits $2 \%$, with an upper limit for the building costs of non-profit housing that is regulated annually. In cases in which rents are considered too high for tenants to afford and the tenant is eligible for housing benefit, the local authorities provide rental support to assist lowincome households. They typically take account of household income, household type/size, the size of the housing unit, and the rent charged by the provider ${ }^{12}$. In return for their co-funding of non-profit housing, local governments have the right to assign 25 $\%$ of vacant dwellings to those in acute need of housing (33\% in Copenhagen).

12 It is not restricted to non-profit housing alone, but applies to all forms of rental housing. 
The main rule governing housing allocation is that vacant dwellings are allocated to people according to time spent on the waiting list. In areas of high demand this can be very long (sometimes several decades), and the rents can be very high. For example, in Copenhagen where housing speculation was responsible for an average increase in property prices close to $45 \%$ between 2000 and 2005 (Kristensen 2007), key workers, such as teachers and nurses, could not afford some of the new social (non-profit) apartments in the city (Scanlon and Vestergaard 2007).

In this regard, Alves and Andersen (2015) claim that "Copenhagen illustrates a classic trade-off between affordability and low growth on one side and on the other economic growth fuelled by increasing property values which in turn drives out the lower income groups from the city centre.” (Alves and Andersen 2015)

It is worth noting that in Denmark non-profit associations are organized in small selfgoverned units in which local tenants enjoy a high degree of democratic decisionmaking, representation, and self-management (Agger and Jensen, 2015). In the so-called 'resident democracy' important decisions, such as major repairs or the level of monthly payments collected from residents, are made by the residents (Kristensen 2007; Jensen 1997; Andersen and Pløger 2007).

\section{The private rental sector}

"Even though the private sector is often regarded as a sector in which market forces dominate, government intervention is far from absent" (Hoekstra et al., 2012: 390). As a result of rent control and legal regulation that protected tenants' rights, and reduced the profitability of landlords, the private rental sector, which was the dominant sector in Portugal and Denmark before the Second World War, has declined and now represents a $20 \%$ share of the total housing stock in both countries.

In Portugal the private rental sector decreased abruptly from $40 \%$ to $20 \%$ between 1981 and 2011 , representing a reduction from $1,074,590$ to 545,710 dwellings in only 30 years (INE 2012). In Denmark the reduction from $40 \%$ to $20 \%$ was more gradual, occurring between 1950 and 2008 (Dol and Haffner 2010). The reduction from 435,000 to 290,000 dwellings between 1970 and 1990 has been explained by the demolition of poor quality private rented dwellings, and the conversion of a large number of dwellings 
into housing co-operatives or owner-occupancy (Andersen and Pløger 2007; Kristensen 2007, 40).

Skifter-Andersen (2014) claims that, since the private rental sector has not been eligible for economic support through direct subsidies, e.g. for direct production or tax reductions, it has not been able to generate housing at affordable rents to compete with non-profit housing. Hence in Denmark, where $55 \%$ of all private rental stock was constructed before the Second World War and only 15\% after 1980, this sector contains some of the oldest, smallest, and lowest quality dwellings (Skifter-Andersen 2014:109). In Denmark rent control in the private rental sector lasted from the Second World War until 1991 when the Danish Parliament decided that new dwellings could be let without control. According to Skak and Bloze (2013): "it was believed to be a decision with no real effect because new dwellings with free market rent would be unable to compete with rent-controlled dwellings. However, new dwellings have since then been built and let at free market rent, and today letting without rent control accounts for close to 10 per cent of the rental market, which covers nearly half of the total housing in Denmark" (Skak and Bloze 2013, 1990). Housing allowances are available in Denmark and perform an essential role in the private rental sector. As Skifter-Andersen (2014) explains: "there are two kinds of allowances for, respectively, pensioners and other tenants, where the allowance for pensioners is much more favourable. The size of the subsidy is dependent on the size of the rent, the size of the dwelling, household income, and household size." (idem: 109).

The most common Danish rent controls applied today are of the second generation type, that is, the softer type, whilst in Portugal these are still part of a so-called 'firstgeneration rent regulation' (Haffner et al. 2012). Conducting an empirical study of the effects of rent control on the supply and maintenance of rental dwellings in Porto and Lisbon, Branco and Alves (2015) conclude that they have had a significantly negative impact on the quality and quantity of housing in the private rental sector in these cities.

In this regard, it is worth noting that rent controls were first introduced in Portugal in 1910, but the freezing of all private sector rents was not implemented in Lisbon and Porto until 1948. With the revolution of 1974, in a context of economic recession and housing shortages, the freezing of rents was extended throughout Portugal. These rules 
allowed sitting tenants to remain in their houses without incurring increased housing costs and, owing to inflation, rents become almost symbolic, namely, designed for tenants of middle incomes who had hitherto paid very low rents. Because property owners have not traditionally made enough money for maintenance or renovation and tenants could not be evicted, the vast proportion of older housing stock has suffered dilapidation. Problems of physical deterioration included a lack of basic amenities inside houses such as bathrooms or kitchens. In 2011 19\% of total rent contracts were established before 1975, 34\% between 1975 and 2005, and 47\% between 2006 and 2011.

Whilst in the 1980s and 1990s several programmes attempted to boost the renovation of the private rental sector, giving housing allowances and tax concessions to landlords to renovate the occupied buildings, limited funding and the complex bureaucracy associated with the programmes curtailed their success (see Branco and Alves 2015).

Figure 7 illustrates the effect of rent control on the distribution of monthly rent levels in Portugal in 2011 (INE, 2012).

The results show an average increase of all rents between 2001 and 2011, with a decrease in the number of homes leased with lower rent values and an increase in intermediate and higher rents, amounting to an overall increase in problems of affordability in this housing market.

Figure 7 about here. Figure 7 - Distribution of monthly rent levels in Portugal in 2001 and 2011; Source: INE (2011).

Statistical evidence shows that the private rental sector in Portugal is composed of two different sub-sectors. On the one hand, there is a sub-sector of low rents characterized by pre-1990 contracts in which market mechanisms have been almost absent. This represents $35 \%$ of all private rental contracts in 2011. In 2011 about $15 \%$ of all rented accommodation in Portugal still carried rents equal, or less than, 35 euros per month. On the other hand, there is a new sub-sector of contracts signed after 1990 dominated by higher rents. In 2011 the average rent in the private rental sector was equivalent to 235 euros. Contracts signed after 1990 tend to be for high rents. 
In 2012 a new law was approved to set a five-year period of transition from the old lease contracts to a new regime of rents (free of rent control mechanisms). In the case of low-income tenants or those with disabilities, the law determines that rent increases will be compensated by housing allowances paid by the state.

\section{The owner-occupancy sector}

After its accession to the European Union in 1986, in a context of economic growth associated with the liberalization of the financial sector and capital flows and the transfer of European Structural Funds which enabled numerous infrastructure investments (e.g. educational and health facilities, highways, bridges), the Portuguese government launched several fiscal, economic, and financial policies to encourage families to buy houses through supported loans.

Analysis of Portuguese spending in the domain of housing by item of expenditure (interest rate subsidies, rehabilitation, bricks-and-mortar subsidies etc.) between 1987 and 2011 reveals that $73 \%$ of total spending in the housing sector was used to support home-ownership through subsidized credit (IHRU 2015). About three-quarters of all public resources were spent on subsidies on bank loans for construction and purchase of homes.

In a context of low interest rates, these government incentives fuelled housing prices and the expansion of home-ownership in Portugal. Between 1981 and 2001, the homeownership rate rose in Portugal from $57 \%$ to $76 \%$ of all housing stock, that is, from 1.6 million to 2.7 million owner-occupied dwellings.

The levels of household debt connected with housing credits increased correspondingly (European Central Bank 2009, 6). Whilst until the mid-1990s the percentage of owneroccupiers with mortgages represented only $14 \%$ of total ownership, in 2001 the figure was already $32 \%$ and in $201143 \%$ of all home-owners, equivalent to 2,923,280 (INE 2013). In 2005 Portugal was already among the European Union Member sSates with the highest burden of private debt in total GDP. In late 2007 the total amount of household debt represented $129 \%$ of disposable income, well above the 2001 figure of 90\%. Easy access to credit in global markets, the absence of incentives to limit loan-to- 
deposit ratios, and insufficient risk perception led to what Pina and Abreu (2012) describe as excessively high consumption and indebtedness in Portuguese society (idem: 1).

Research shows that government subsidies for home-ownership tend to benefit the economically well-off with easier access to credit, namely in countries with very high levels of inequality such as Portugal (Carmo et al. 2014; Bergenstråhle 2015, 2; Dewilde and Decker 2015: 6; Alves 2015:11), where, according to Allen et al. (2004), there is also a 'double deficit of stateness' (idem, 72) characterized by less direct state provision and welfare institutions that are more vulnerable to partisan pressure and manipulation (Allen et al. 2004, 96).

According to empirical evidence presented by Norris and Winston (2012), between 1990 and 2004 lower interest rates and government incentives to buy fuelled the expansion of home-ownership rates in most western European countries, Denmark being one of the few exceptions (Norris and Winston 2012).

The pattern of Danish housing differs from the Nordic and European norm, being characterized by a smaller expansion of owner-occupancy owing to policies which have not promoted home-ownership while offering alternatives in the rental market. However, it is worth noting that the limited expansion of owner-occupancy has occurred in a context of the wider availability of credit in the markets and public incentives to home-ownership (tax reductions for private owners) which have made the purchase of property more advantageous (Andersen and Pløger 2007). During the period 1982-1990, during which Denmark was governed by a series of coalitions consisting of liberal or conservative parties, several important measures were introduced to prevent the national debt from increasing. In the 1980s [right-wing] governments altered taxation, reducing the level of indirect subsidies to home buyers (Skifter-Andersen 2011; Alves and Andersen 2015) and introducing a counter-cyclical subsidy policy to expand resources allocated to the non-profit rented housing sector.

According to Skifter-Andersen $(2011,19)$, Denmark is now the only Nordic country without any individual subsidies or supply subsidies for home-owners. Only general support via the tax system is available while no support finance exists. Nevertheless, 
Denmark has high levels of indebtedness and the overburden rate $^{13}$ of Danish households remains particularly high (Pittini 2011).

Since 2006 Danish housing policy has gradually evolved from supporting housing supply to supporting households, meaning more use of housing allowances and less use of 'bricks-and-mortar' subsidies, which remain substantial, notably through public copayment of mortgages used to finance new social dwellings (Alves and Andersen, 2015).

\section{Housing Outcomes in Portugal and Denmark}

This empirical section on housing outcomes is based upon statistical data extracted from the [EU] Statistics on Income and Living Conditions (EU-SILC) and on data collected from the 2011 census on housing conditions (cf. Statistics Denmark 2013; INE 2012).

This section discusses the similarities and differences between what is predicted by Kemeny's theories of integrated and dualist rental systems and what is observed in these countries in terms of dwelling conditions and household composition.

\section{Housing quality}

The relationship between rental systems and housing deprivation has been tested by Borg (2015) who finds a negative association between the size of the rental sector and the prevalence of housing deprivation. Her work validates Kemeny's claim that integrated rental systems lead to higher quality housing across tenures than do dualist rental systems. This conclusion is also valid for the comparison of housing quality in Portugal and Denmark when a wide range of aspects are taken into account, such as those related to structural problems (damp walls, leaking roof, etc.), overcrowding, or lack of basic amenities (e.g. an adequately heated residence).

One of the key dimensions in assessing the quality of housing conditions is the availability of sufficient space in the dwelling. The overcrowding rate describes the proportion of people living in an overcrowded dwelling, which is defined as the number

13 The share of housing costs in income. 
of rooms available given the household size and composition. In 2012 10\% of the overall Portuguese population lived in overcrowded dwellings while the figure was $7.4 \%$ in Denmark. ${ }^{14}$ The rate of overcrowding among the population at risk of poverty ${ }^{15}$ was nevertheless higher in the Danish case than in the Portuguese, even though the population at risk of poverty is lower in Denmark than in Portugal, $16.9 \%$ and $21 \%$ respectively (see Alves, 2015).

The housing stock in Portugal has clearly improved since 1970 (Figure 8), when the expansion of illegal settlements often built with inferior materials and without access to basic comfort infrastructure led to very poor housing conditions. By 2011 several housing quality problems nevertheless persisted. According to INE (2012), of all buildings built before 1919 , only $38 \%$ do not show repair needs, and $11 \%$ of these are in very poor condition (see Branco and Alves, 2015).

Figure 8 about here. Figure 8 - The evolution of the basic comfort infrastructure in Portuguese dwellings 1970-2011. Source: INE, 2011.

In 2012 humidity or leaking roofs affected one third of the Portuguese population (EUSILC 2012), and the proportion of buildings in need of major repairs stood at $4.4 \%$, a value that increased in Lisbon and Porto to 7\% (Branco and Alves 2015).

Conservation status in Portugal and Denmark was at its worst in 2012 in the private rental sector, specifically in old buildings that were or have been subject to strict rent regulation which affected their maintenance (Skifter-Andersen 2014; Branco and Alves 2015).

In $201210.8 \%$ of the EU-28 population was unable to keep their homes adequately heated owing to financial restrictions (Eurostat 2014, 58). In Portugal the share of the population that could not afford adequate heating was higher, corresponding to $27 \%$ of the population. The situation was even worse for the population at risk of poverty, corresponding to $43 \%$ (Figure 9).

14 The highest overcrowding rates are registered in Romania (51.6\%), Hungary (47.2\%), Poland (46.3\%), Bulgaria (44.5\%), and Croatia (44.1\%) (Eurostat 2014).

15 Those living in households where the equivalent disposable income per person was below $60 \%$ of the national median. 
Figure 9 about here. Figure 9: Rates of inadequate heating, 2008, 2010, and 2012 (\% of specified population); Source: Eurostat 2014.

\section{Housing affordability}

According to Eurostat, in $201211.2 \%$ of the EU-28 population lived in households that spent $40 \%$ or more of their equivalised disposable income on housing. This share was lower in Portugal (equivalent to $8.3 \%$ ) and higher in Denmark, equivalent to almost one fifth of the total population (18.2\%) (Figure 10).

Figure 10 about here. Figure 10: Housing cost overburden rate by tenure status, 2012 (\% of population). Source: Eurostat 2014.

The proportion of the population in which housing costs exceeded $40 \%$ of their disposable income was highest in Portugal for tenants with market price rents (35.9\%) and lowest for persons in owner-occupied dwellings without a loan or mortgage $(2.8 \%)$. In Denmark in 2012, the $50 \%$ of tenants enjoying reduced rents exceeded $40 \%$ of their disposable income, which demonstrates that tenants in the non-profit sector face affordability problems in Denmark (Dewilde and Decker 2015, p. 18) and only 6\% in Portugal. The rate of housing cost overburden is practically the same in both countries in the case of tenants in the private rental market, that is, about $34 \%$.

\section{For-profit / Private rental}

In Portugal the private rental sector can be split into two sub-sectors. On the one hand, there is a sector of older dwellings that have been subject to first- generation rent regulation (see Haffner et al. 2012). negatively affecting the maintenance of these dwellings and housing quality problems are relatively common. On the other hand, there is a segment living in renovated or recently built housing in which dwellings tend to be relatively expensive and of good quality. Here tenants have on average higher incomes and a lower level of welfare dependence.

To promote investment in the renewal of the private rental sector, in Denmark the government made legal changes to boost housing renewal. One change highlighted by Skifter-Andersen (2014) enabled the transition from a 'strong' to 'softer' rent control in 
the case of private landlords who would invest a certain amount of money per square metre in a vacant dwelling. In this soft regulation regime there are only vague rules about how to determine the rent, hence the rent should not be considerably higher than rents in similar dwellings in the local area. According to Skifter-Andersen (2014), "28 per cent of lettings under strict rent control have been transferred to 'soft control' with rents closer to market level" (idem: 113) and, especially in Copenhagen, this has had a marked effect on the increase of rents (see Alves and Andersen, 2015).

Housing allowances have broad coverage in Denmark, being granted to more than 530,000 households in social housing and private rental housing, equivalent to more than one fifth of all Danish households. About 58\% and 36\% of the tenants in these two segments respectively receive housing allowances which on average cover $47 \%$ and $38 \%$ of the actual rents paid (OECD 2006, 116).

\section{Non- profit/Social housing}

As emphasized elsewhere, in Denmark the rental sector is an important alternative to owner-occupation. The Danish rental sector differs from that in Portugal in two respects. In the first place, it is characterized by considerable government activity and regulation, not being marked by insecurity of tenure and low maintenance standards, and covers broad classes of the population. In the second place, in Portugal the social housing rental market is formulated as a safety net for the poor, so the quality of the housing stock is relatively low, the dwellings badly maintained, and provided in a residualized way. As predicted by Kemeny $(2006,3)$, this protected housing tenure, which is targeted at low-income households, leads to stigmatization and segregation in Portugal (Alves and Andersen 2015).

\section{Owner- occupancy}

In Denmark home-owners are to a large extent middle- and high-income earners, while in Portugal, where the owner- occupancy sector is the dominating tenure type, the sector covers a more diverse range of families. 
In 2011 more than $80 \%$ of the families of the two classes with higher incomes (4th and 5th quintiles) were home-owners (83.5\% and $87.6 \%$ respectively), while $53.2 \%$ of households belonging to the lower income class (1st quintile), held the property (INE 2012, 71). (See Figure 11).

Figure 11 about here. Figure 11 - Housing tenure by income quintiles in Portugal 2011; Source: INE 2012.

Whilst in Denmark housing conditions in the owner-occupancy sector are quite favourable, in Portugal where the driving force behind home-ownership rates has been the lack of alternatives in the rental market, this is not always the case. Informal routes of self-provision within the extended family in a context of weak land use regulation have led to urban sprawl and suboptimal housing outcomes.

The Portuguese case proves Dewilde and Decker's claim (2015) that in countries with a more commodified housing regime, suboptimal housing outcomes may either result from higher reliance on the market, or from the more pronounced role of the family in self-promotion, poor building standards, and overcrowding (Dewilde and De Decker 2015).

In 2012 Portugal had one of the highest income disparities of all EU-28 countries (Eurostat 2014, 21), and large gaps in the distribution of income between the lower and upper strata find expression in material living, in which housing conditions are a paradigmatic domain.

As Wall et al. (2001) have shown: "welfare provision stemming from informal relationships reinforces existing social inequalities rather than compensating for them" (Wall et al. 2001, 213). Family support tends to be significantly lower in the case of low-income families than within well-off families, plus 'familialist' methods of support tend to reduce the disposable income within families with less economic resources (salaries and accumulated wealth). Family support represents an economic transfer but not an increase in resources. In the case of low-income families, the sharing of resources within the family (e.g. older to younger) may imply greater exposure to the risk of poverty among the elderly. 
Over the last decade, Portugal has also faced a huge problem of defaulting mortgages that affected over-indebted households that, in a context of high unemployment rates (see Alves 2015), could not repay their debts. Of the 2,292,920 families with loans granted by banks, in $20166.5 \%$ are experiencing mortgage arrears.

\section{Conclusion}

The aim of this paper is to test Kemeny's typology of rental systems $(1995,2006)$ on a bi-country comparison of housing systems that belong to different welfare state regimes - Portugal and Denmark.

A combination of sources was used to explain divergence in the long-term structuration of the housing systems of these countries and their housing outcomes, such as documentary literature, interviews, analysis of primary statistical data.

The empirical results of my analyses largely support Kemeny's theories, supporting the three hypotheses initially formulated in this paper. Several conclusions can be drawn from the analysis.

- Kemeny's claim that ideologies translate into housing policies and dominant forms of tenure and housing outcomes is true. High home-ownership rates in Portugal are to a great extent the result of policies that have strongly supported the growth of home-ownership, while discouraging investment in the rental sector. The driving force behind increasing home-ownership rates has been both active support for this form of tenure and the lack of government support for other forms of tenure. This is contrary to the Danish case.

- The Danish housing system is a perfect illustration of an integrated rental system, showing a striking balance between rental and owner-occupancy tenures, and in the former limited differences between housing quality and rent levels.

- The Portuguese housing system, characterized by an overwhelming share of owner-occupancy, is an 'exotic variation' of the dualist rental system in 
which large differences exist not only between sectors (e.g. owneroccupancy and rental) but also within each sector, according to the government and family strategies that have led to its provision.

Divergences between these two housing systems are explained by the prevalence in Denmark of social democratic ideologies that have supported social equality and longterm investment in the rental sector, namely in a non-profit market delivered by nonprofit associations. Meanwhile, in Portugal corporatist ideologies, first during the Salazar regime [1933-74] and subsequently during the period of socialist and socialdemocratic governments, have supported owner-occupation at the expense of the rental sector. While the former was characterized by a laissez faire phase of residual state intervention in which a huge percentage of the population inhabited unhealthy housing that did not meet basic human needs, most of this housing being the result of several forms of family self-promotion, the latter, since the 1980s, has been characterized by a 'pro-owning' phase in which government incentives (subsidized loans, tax deductions) compelled families to buy or build their own homes through mortgage loans.

The empirical evidence presented in this paper does not support Norris and Winston's (2012) claim that Kemeny's (1995) typology is not able to capture the most significant inter-country cleavages, namely between northern and southern European countries (Norris and Winston, 2012: 36). On the contrary, Kemeny's theories are very useful for explaining many of the observed divergent features of these housing systems, and for predicting the development of housing systems in other countries.

However, some adjustments, based upon the differences between Kemeny's theories of dualist rental systems and what was found in the Portuguese case, expand its explanatory power. This claim can be justified on two grounds. On the one hand, as anticipated by Kemeny (2006, 3), housing policies in Portugal have indeed promoted i) a very large owner-occupancy sector, and ii) a very small public social housing sector targeted at the low-income stratum. On the other hand, contrary to Kemeny's theory, dualist rental systems may not be characterized by a deregulated 'private' housing sector, but may be made up, as the Portuguese case shows, of two sub-markets of rent contracts. On the one hand, a market that has been highly regulated and is, therefore, still characterized by low rents and poor housing standards (which explains the derelict 
run-down scenario of some city centres), and, on the other hand, a new deregulated submarket associated with high rents.

Another conclusion that this paper draws is that affordable housing can be obtained through different routes, both through the rental market and owner-occupancy tenure (e.g. forms of self-construction), but not all of them ensure satisfactory standards of housing for all social groups. In Portugal, as in other southern European countries, poor housing conditions are concentrated among households on the lowest incomes, while in Denmark, and in other unitary regimes, low-income households live in relatively good housing conditions (Norris and Winston 2012, 135).

\section{References}

Agger, Annika, and Jesper Ole Jensen. 2015. "Area-based Initiatives-And Their Work in Bonding, Bridging and Linking Social Capital." European Planning Studies 23 (10): 2045-2061.

Alves, S. In press. "Assessing the impact of area-based initiatives in deprived neighbourhoods: the example of S. João de Deus in Porto, Portugal", Journal of Urban Affairs, Accepted for publication March 2016.

Alves, Sónia. 2015. "Welfare State Changes and Outcomes: the Cases of Portugal and Denmark from a Comparative Perspective." Social Policy \& Administration 49 (1): 123.

Alves, Sónia, and Hans Thor Andersen. 2015. "Social housing in Portugal and Denmark: a comparative perspective". Paper presented at the ENHR 2015 Lisboa, June July, 28-1.

Allen, Judith, James Barlow, Jesús Leal, Thomas Maloutas, and Liliana Padovani. 2004. Housing \& Welfare in Southern Europe, London: Blackwell Publishing.

Andersen, John, and John Pløger. 2007. "The Dualism of Urban Governance in Denmark." European Planning Studies, 15 (10): 1349-1367.

Andersen, Hans Thor, and Lars Winther. 2010. "Crisis in the Resurgent City? The Rise of Copenhagen." International Journal of Urban and Regional Research, Volume 34 (3): 693-700.

Balchin, Paul. 1996. Housing policy in Europe. New York: Routledge 
Ball, Michael, Michael Harloe, and Maartje Martens. 1988. Housing and Social Change in Europe and the USA, London: Routledge.

Bergenstråhle, Sven. 2015. "About tenure neutrality: a critical response to Quentin Bradley." International Journal of Housing Policy, ahead-of-print: 1-4.

Bengtsson, Bo, and Ruonavaara, Hannu. 2010. "Introduction to the special issue: path dependency in housing." Housing, Theory and Society, 27 (3): 193-203.

Bengtsson, Bo, and Ruonavaara Hannu. 2011. "Comparative Process Tracing in Housing Studies." International Journal of Housing Policy, 11(4): 395-414.

Bengtsson, Bo. 2015. Between Structure and Thatcher. Towards a Research Agenda for Theory-Informed Actor-Related Analysis of Housing Politics, Housing Studies. 30.5, 677-693.

Borg, Ida (2015) Housing Deprivation in Europe: On the Role of Rental Tenure Types, Housing, Theory and Society, 32:1, 73-93, DOI: 10.1080/14036096.2014.969443

Branco, Rosa, and Sónia Alves. 2015. "Affordable housing and urban regeneration in Portugal: a troubled tryst?. Paper presented at the ENHR 2015 Lisboa, June July, 28-1.

Carmo, André, João Ferrão, and Jorge Malheiros. 2014. "Geografias do Estado social: reorganização territorial, habitação e urbanismo." In Estado social: de todos para todos, edited by Renato Carmo M. Barata, 167-200. Lisboa: Tinta da China.

Cash, John Daniel. 1996. Identity, ideology and conflict: The structuration of politics in Northern Ireland. Cambridge University Press.

Dewilde, Caroline, Pascal De Decker. 2015. "Changing Inequalities in Housing Outcomes across Western Europe, Housing, Theory and Society", DOI:10.1080/14036096.2015.1109545

Dol, Kees and Mariette Haffner. 2010. Housing Statistics in the European Union, The Hague: Ministry of the Interior and Kingdom Relations, OTB Research Institute for the Built Environment. Delft University of Technology.

Doling, John. 2012. "Housing Policy Trends." in International Encyclopedia of Housing and Home, edited by S.J. Smith, Amsterdam: Elsevier.

European Central Bank. 2009. Housing finance in the Euro area, Frankfurt, Germany.

Eurostat. 2014. Living conditions in Europe. Luxembourg: Publications Office of the European Union

Eurostat. 2015. http://ec.europa.eu/eurostat/ Accessed 04 February 2016. 
Elsinga, Marja, and Joris Hoekstra. 2005. "Homeownership and housing satisfaction." Journal of Housing and the Built Environment 20 (4): 401-424.

Esping-Andersen, G. (1990), The Three Worlds of Welfare Capitalism, Cambridge: Polity Press and Princeton, NJ: Princeton University Press.

Haffner Marietta, Elsinga M. and Hoekstra Joris (2012) Access and Affordability: Rent Regulation, Elsevier, pp. 40-45.

Hansen, Frank, and Carlos Nunes Silva. 2000. "Transformation of the welfare states after World War 2: the cases of Portugal and Denmark", Environment and Planning C: Government and Policy, 18 (6): 749-771.

Harloe, Michael. 1995. The people's home? Social rented housing in Europe \& America, Oxford: Blackwell.

Hoekstra, Joris. 2009. "Two types of Rental System? An Exploratory Empirical Test of Kemeny’s Rental System Typology." Urban Studies, 46 (1): 45-62.

IHRU. 2015. 25 anos de esforço do orçamento do estado com a habitação 1987-2011. Lisboa: Instituto da Habitação e da reabilitação urbana.

INE. 2012. Recenseamento Geral da População e Habitação, Lisboa. https://www.ine.pt/ (accessed 04 February 2016).

INE. 2013. O Parque Habitacional e a sua Reabilitação: análise e evolução 2001-2011. Lisboa: Instituto Nacional de Estatística /LNEC.

Jensen, Lotte. 1997. "Stuck in the middle? Danish social housing associations: between state, market and civil society" Scandinavian Housing and Planning Research, 14 (3): 117-131.

Kemeny, Jim. 1992. Housing and Social Theory, London, Routledge.

Kemeny, Jim. 1995. From public housing to the social market: Rental policy strategies in comparative perspective. Routledge.

Kemeny, Jim and Stuart Lowe. 1998 "Schools of comparative housing research: from convergence to divergence." Housing studies, 13(2), 161-176.

Kemeny, Jim. 2001. "Comparative housing and welfare: Theorising the relationship." Journal of Housing and the Built Environment 16: 53-70.

Kemeny, Jim. 2006. "Corporatism and Housing Regimes." Housing, Theory and Society, 23 (1): 1-18.

King, P. 2012 "Political ideologies", in International Encyclopedia of Housing and Home, edited by S.J. Smith, Amsterdam: Elsevier 
Kristensen, Hans. 2007. Housing in Denmark, Centre for Housing and Welfare, Copenhagen: Realdania Reserch.

Lujanen, Martti. 2004. Housing and Housing Policy in the Nordic Countries. Copenhagen: Nordic Council of Ministers.

Malpass, Peter and Alan Murie. 1998. Housing Policy and Practice, England, Palgrave.

Malpass, Peter. 2011. "Path dependence and the measurement of change in housing policy." Housing, Theory and Society, 28(4), 305-319.

Norris, Michelle and Nessa Winston. 2012. "Home-ownership, housing regimes and income inequalities in Western Europe." International Journal of Social Welfare, 21 (2): 127-138.

OECD. 2006. Housing: Less subsidy and more flexibility, in OECD Economic Surveys: Denmark, p. 107 - 161.

O'connor, Julia S. 1993. "Gender, class and citizenship in the comparative analysis of welfare state regimes: theoretical and methodological issues". British journal of Sociology 44 (3): 501-518.

Oxley, Michael. 2001. "Meaning, science, context and confusion in comparative housing research." Journal of Housing and the Built Environment, 16: 89-106.

Oxley, Michael and Haffner, M. 2012. "Comparative Housing Research". In: Susan J. Smith et al. eds. International Encyclopedia of Housing and Home, Vol 1. Oxford: Elsevier, pp. 199-209.

Pina, Alvaro and Ildeberta Abreu. 2012. "Portugal: Rebalancing the Economy and Returning to Growth Through Job Creation and Better Capital Allocation." OECD Economics Department Working Papers, No. 994, OECD Publishing. http://dx.doi.org/10.1787/5k918xjjzs9q-en (accessed 5th June, 2013).

Pittini, A., and E. Laino. 2011 "Housing Review 2012: The nuts and bolts of European social housing systems." Brussels, CECODHAS Housing Europe's Observatory.

Ruonavaara, Hannu. 1993 "Types and forms of housing tenure: Towards solving the comparison/translation problem”, Scandinavian Housing and Planning Research, 10:1, 3-20.

Scanlon, Kathleen, and Hedvig Vestergaard. 2007. "Social housing in Denmark", in Social Housing in Europe. London, London School of Economics, edited by C. Whitehead and K. Scanlon, 44-54.

Schwartz, H. 2012. "Welfare States and Housing", in International Encyclopedia of Housing and Home, edited by S.J. Smith, 267-272, Amsterdam: Elsevier. 
Smas, Lukas, Christian Fredricsson and Haukur Claessen. 2013. "Demographic changes, housing policies and urban planning: Examples of situations and strategies in Nordic municipalities."

Skak, Morten, and Gintautas Bloze. 2013. "Rent control and misallocation." Urban Studies 50 (10): 1988-2005.

Skifter-Andersen, Hans. 2011. "Motives for tenure Choice during the Life Cycle: The importance of Non-Economic factors and other Housing Preferences." Housing, Theory and Society, 28 (2): 183-207.

Skifter-Andersen, Hans. 2012. Housing policy in the Nordic countries and its implication for the housing of immigrants, Danish Building Research Institute, Aalborg University.

Skifter-Andersen, Hans. 2014. "Denmark", in T. Crook \& P.A. Kemp (eds) (2014) Private Rental Housing: comparative perspectives. Cheltenham: Edward Elgar, p. 99124

Sørvoll, Jardar. 2009 The Political Ideology of Housing and the Welfare State in Scandinavia 1980-2008: Change, Continuity and Paradoxes, Paper presented at the Reassess Mid-term Conference in Oslo, 18-20 May.

Stamsø, Mary-Ann. 2010. "Housing and Welfare Policy - Changing Relations? A Cross-National Comparison." Housing, Theory and Society, 27 (1): 64-75.

Statistics Denmark. 2013. Statistical Yearbook 2013. Statistics Denmark: Copenhagen, Denmark.

Tress, Gunther. 2007. "Seasonality of second-home use in Denmark." Seasonal Landscapes, Springer Netherlands, 151-179.

Wall, Karin, Aboim, Sofia, Cunha, Vanessa and Vasconcelos, Pedro (2001), Families and informal support networks in Portugal: the reproduction of inequality, Journal of European Social Policy, 11, 3: 213-33. 
Figure 1 - Distribution of population by tenure status: Portugal from 1960 to 2011

Source: INE (2012).

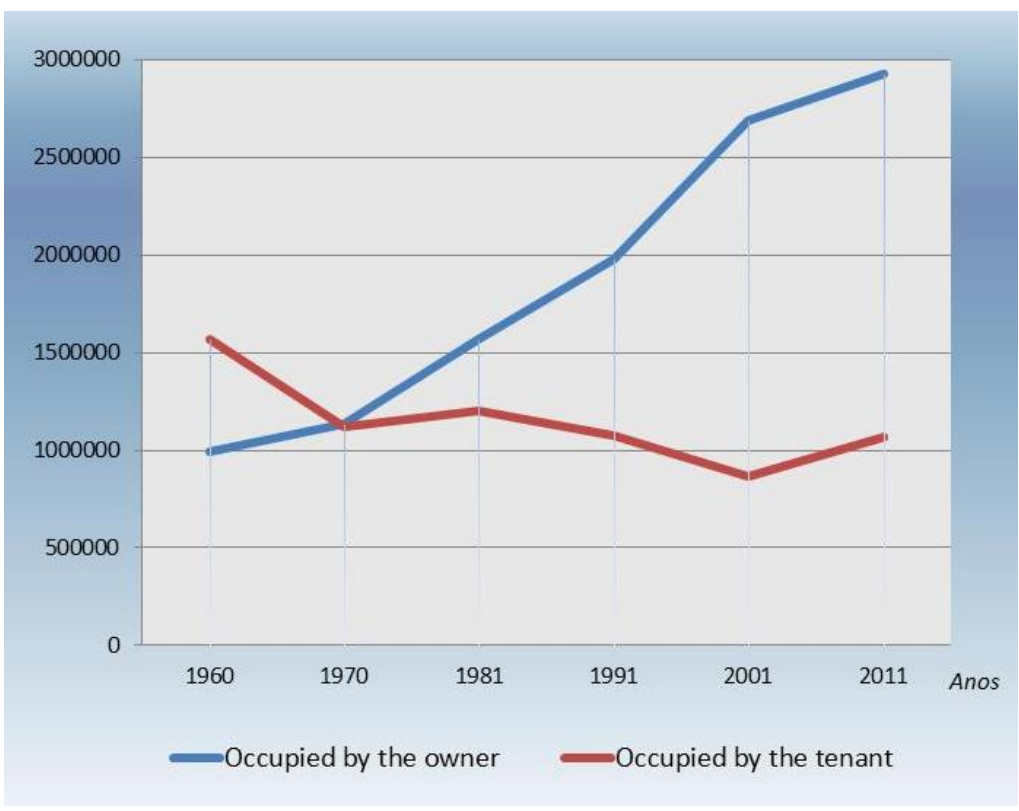

Figure 2 - Distribution of population by tenure status: Denmark from 1960 to 2011

Source: Statistics Denmark (2013)

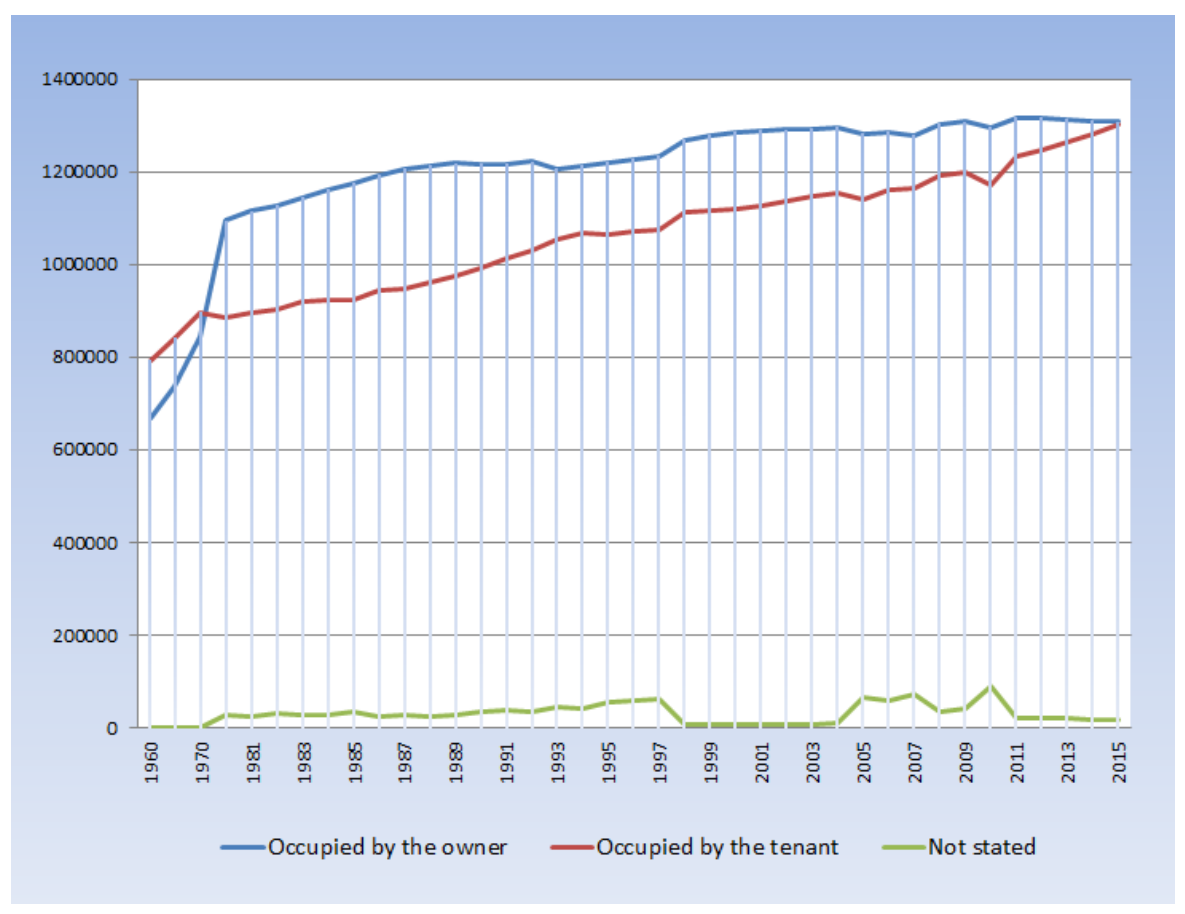


Figure 3 - Age distribution of housing stock in Portugal and Denmark

Source: Statistics Denmark (2013); INE (2012).

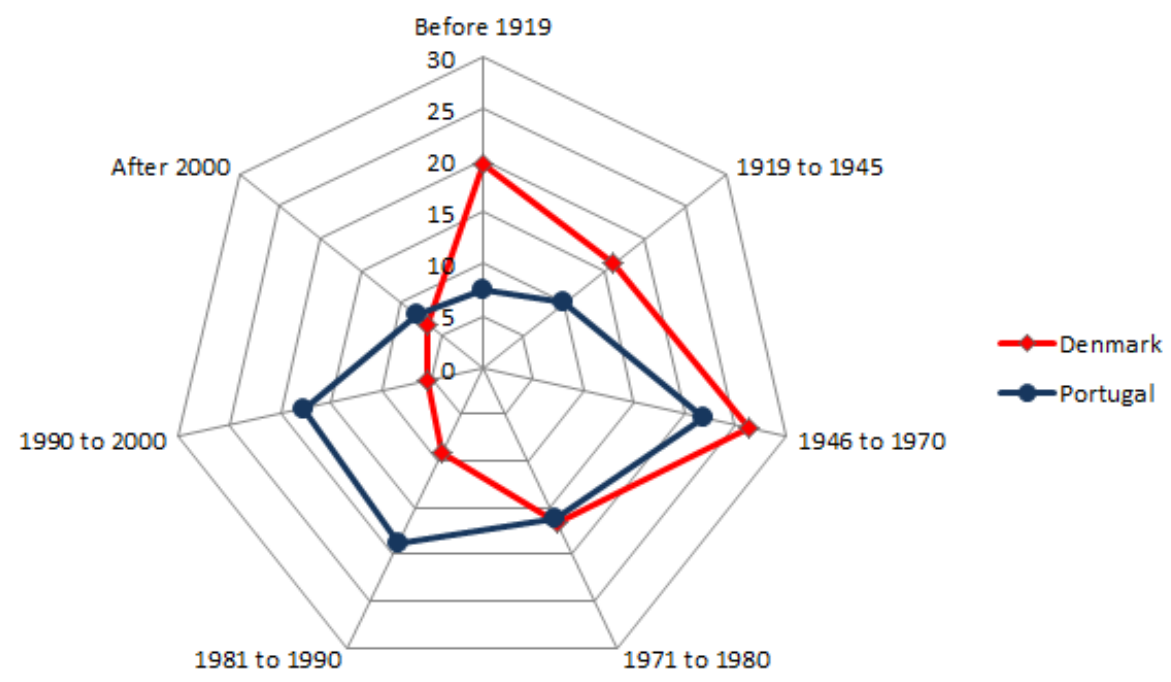

Figure 4 - Total general government expenditure as a percentage of gross domestic product (GDP) 2007-2014

Source: Eurostat (2015)

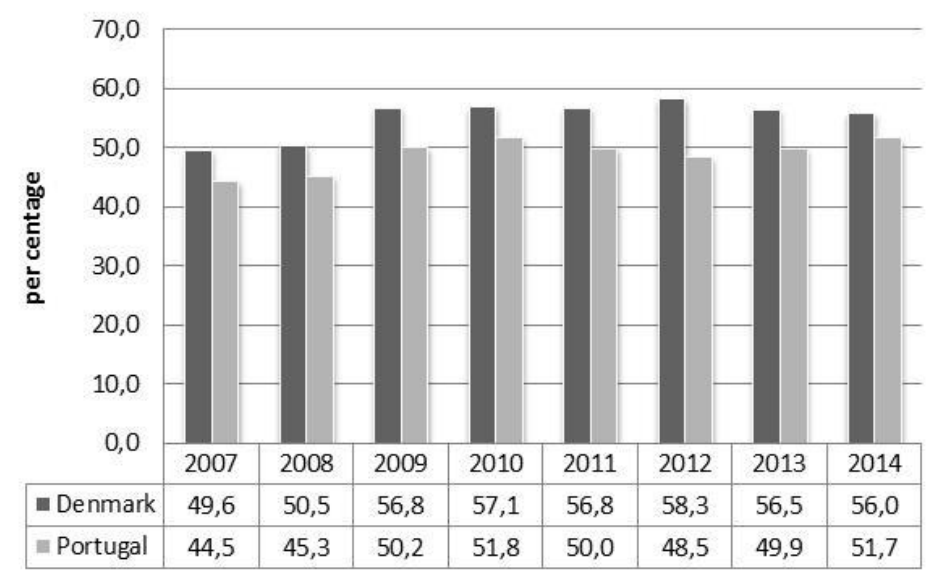


Figure 5 - Total social expenditure on housing in Portugal and Denmark 2012

Source: Statistics Denmark (2013); INE (2012).
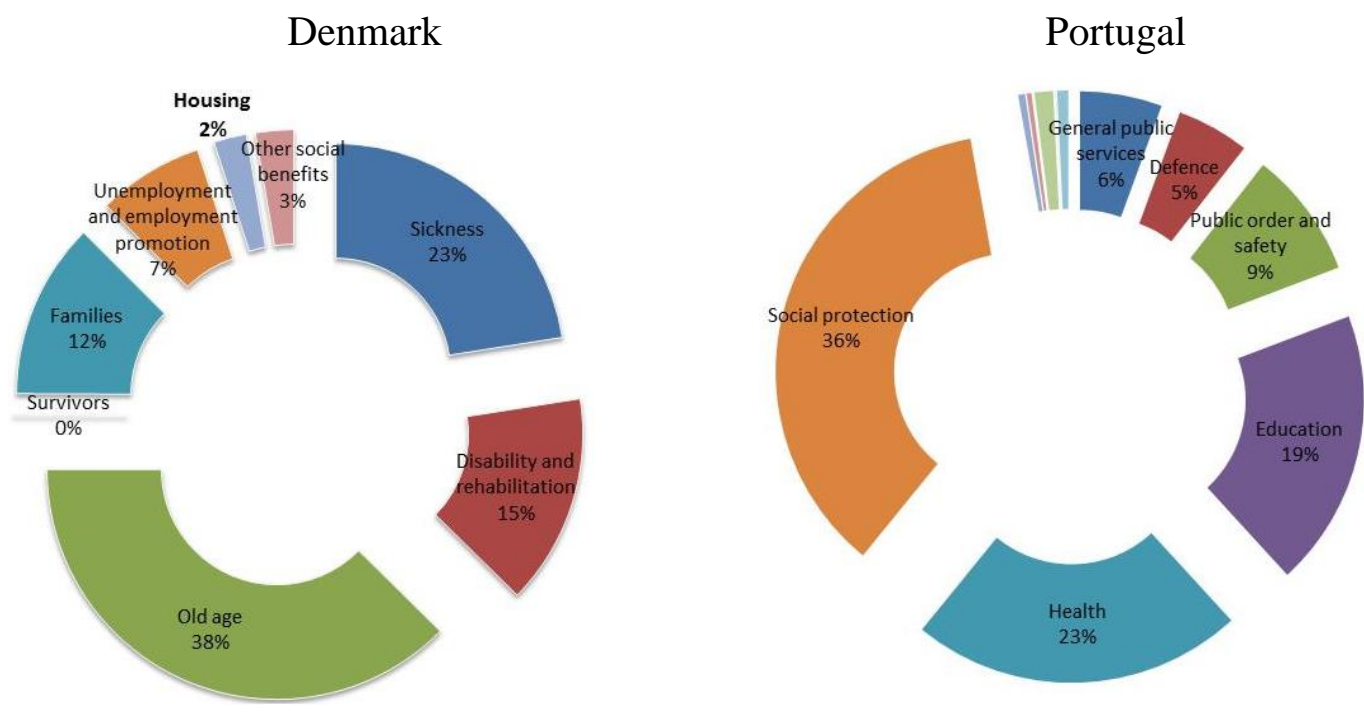

Figure 6 -Total government expenditure on housing in Portugal (in euros) and Denmark (DKK) 1996-2010

Source: Statistics Denmark (2013); INE (2012).

Denmark

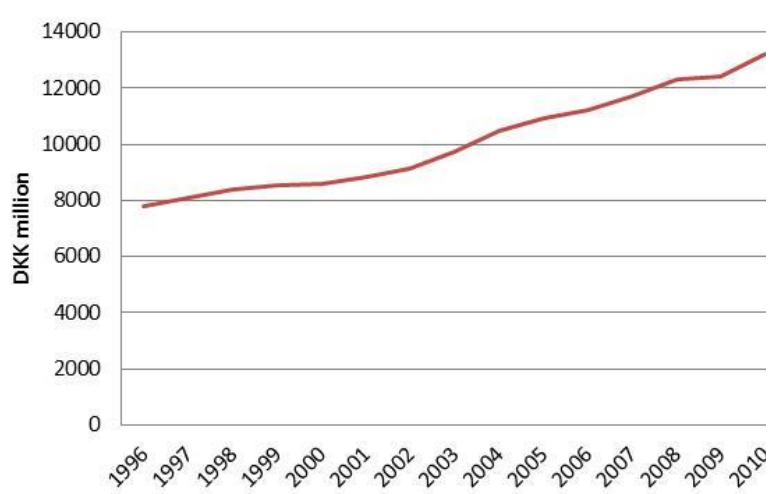

Portugal

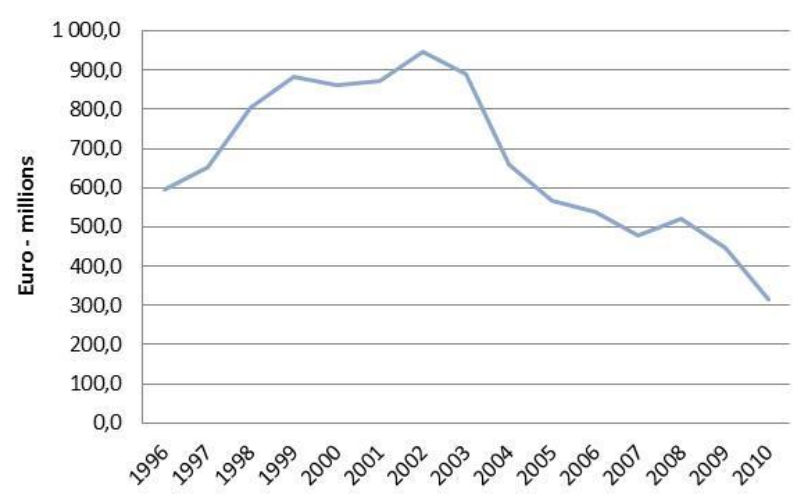


Figure 7 - Distribution of monthly rent levels in Portugal in 2001 and 2011

Source: INE (2011)

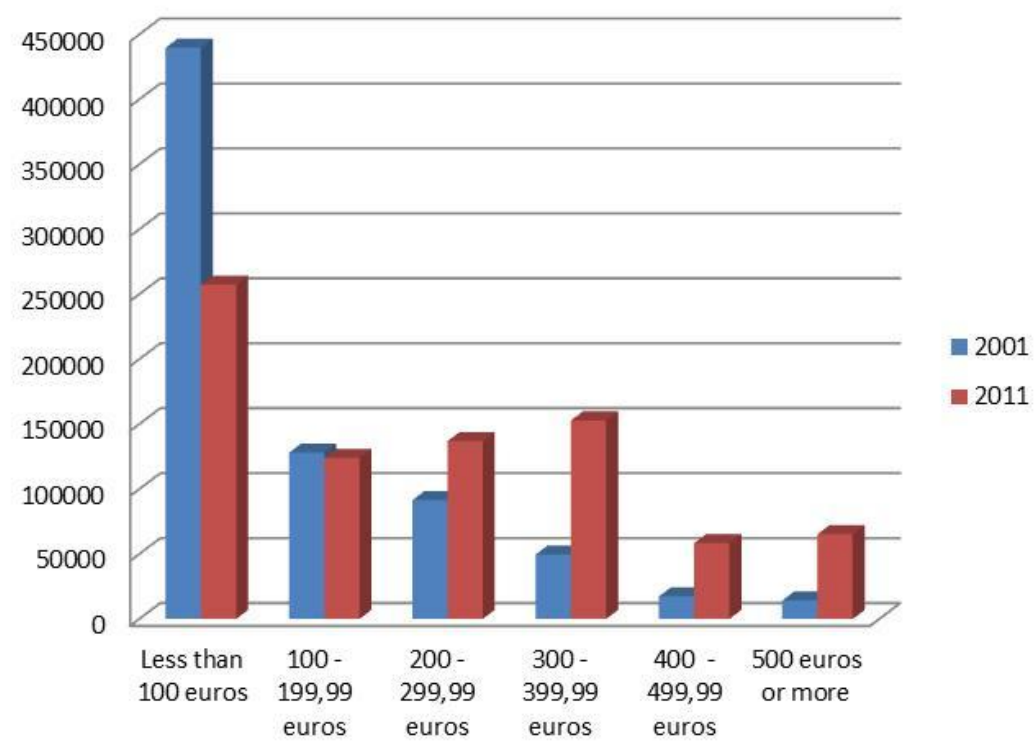

Figure 8 - The evolution of the basic comfort infrastructure in Portuguese dwellings 1970-2011.

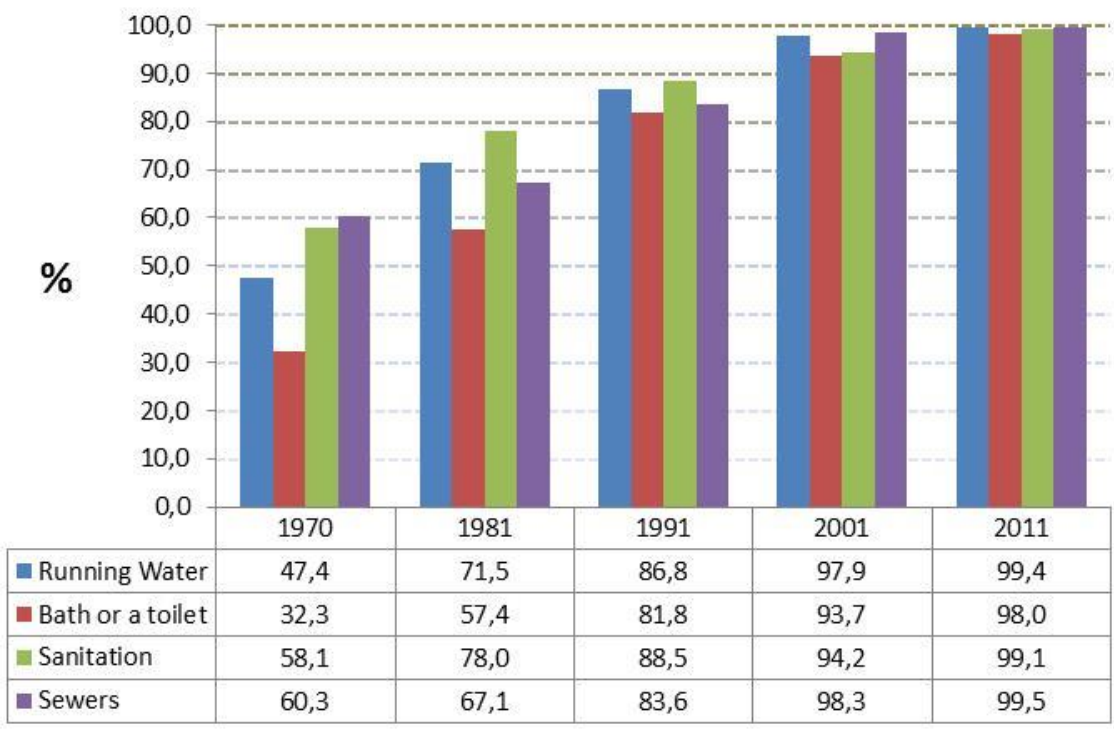

Figure 9: Rates of inadequate heating, 2008, 2010, and 2012 (\% of specified population).

Source: Eurostat 2014. 


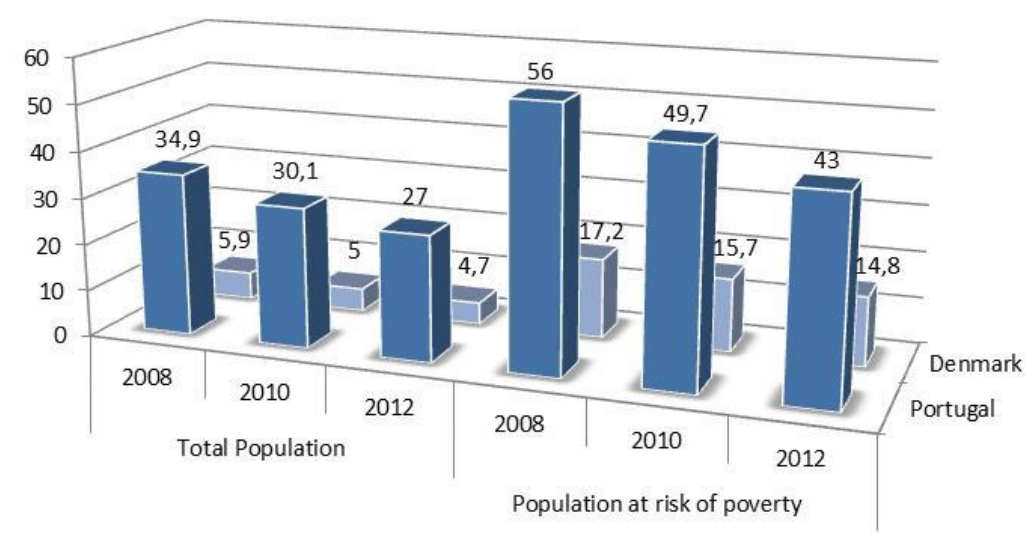

Figure 10: Housing cost overburden rate by tenure status, 2012 (\% of population).

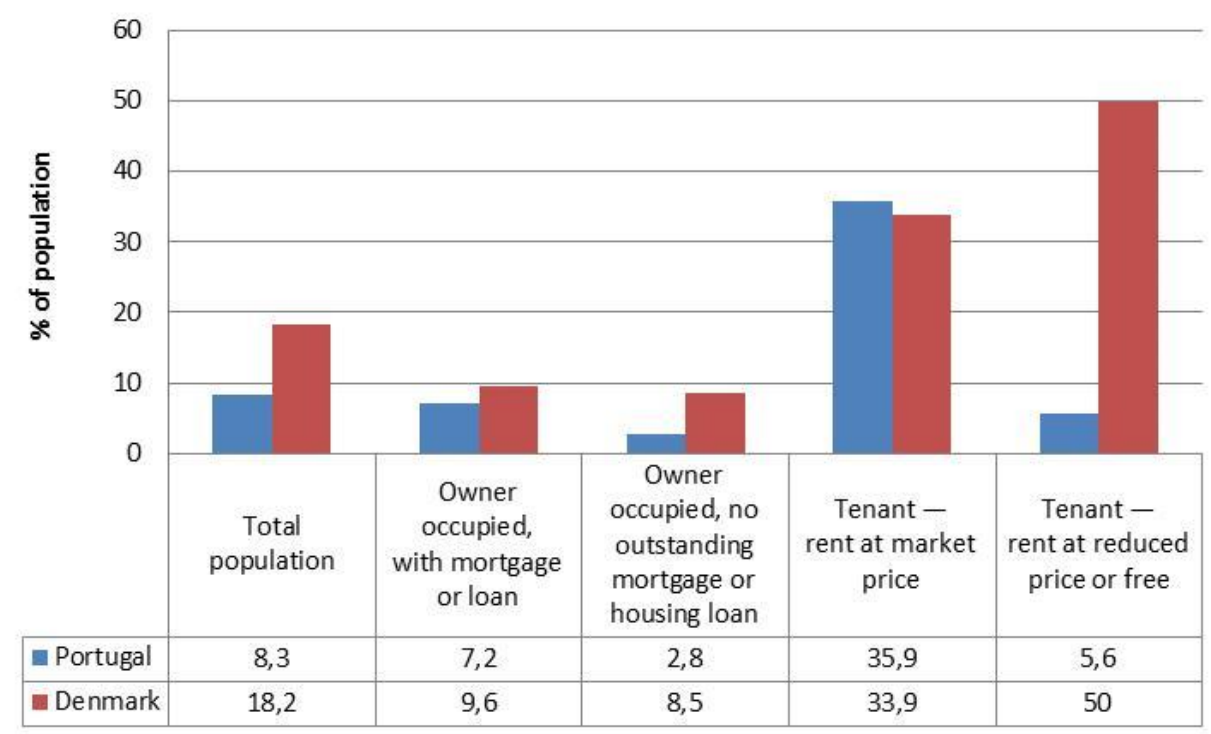

Figure 11 - Housing tenure by income quintiles in Portugal 2011

Source: INE 2012. 


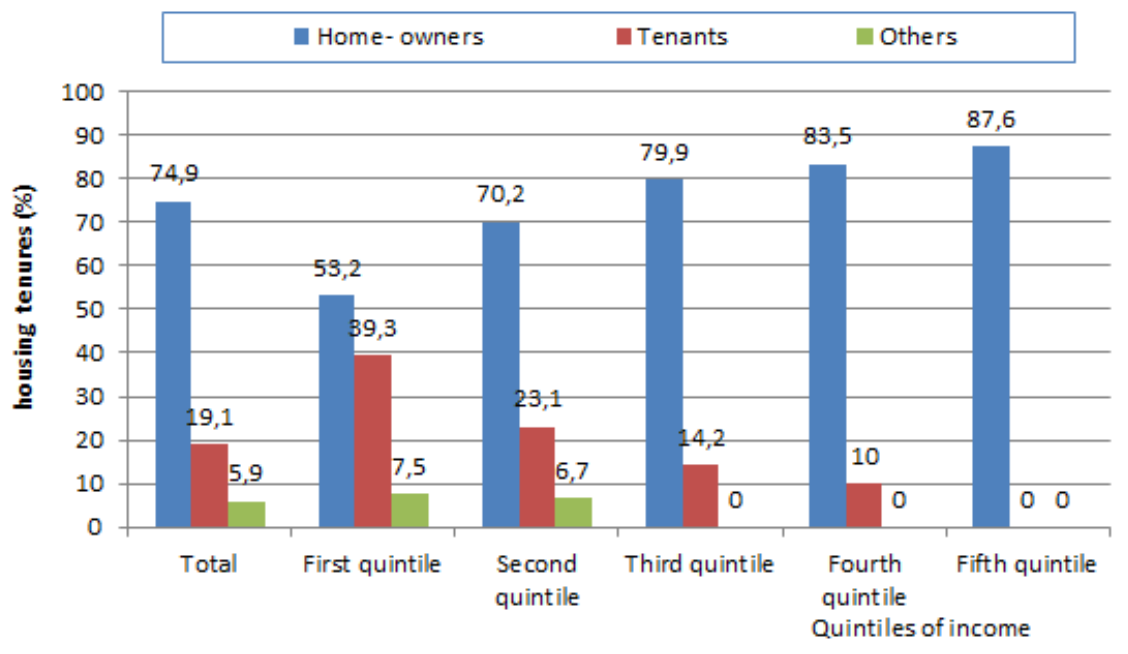




\section{Tables}

Table 1 - General data on demographic and socio-economic context and housing.

\begin{tabular}{|c|c|c|c|c|c|c|c|c|}
\hline & \multirow[t]{3}{*}{$\mathrm{Km}^{2}$} & \multirow{3}{*}{$\begin{array}{c}\text { Pop. } \\
(* 1,000) \\
(2009)\end{array}$} & \multirow{3}{*}{$\begin{array}{l}\text { Pop/km² } \\
(2009)\end{array}$} & \multicolumn{2}{|c|}{ GDP per capita/ } & \multirow{2}{*}{\multicolumn{2}{|c|}{$\begin{array}{l}\text { Total dwelling }(* 1,000) \\
{ }^{\mathrm{a}}(2012)^{\mathrm{b}}(2011)\end{array}$}} & \multirow{3}{*}{$\begin{array}{l}\text { Dwellings per } 1000 \\
\text { inhabitants } \\
{ }^{\mathrm{a}}(2009)^{\mathrm{b}}(2011)\end{array}$} \\
\hline & & & & \multirow[t]{2}{*}{ (1995) } & \multirow[t]{2}{*}{ (2009) } & & & \\
\hline & & & & & & Total & Occupied & \\
\hline Denmark & 43094 & 5,511 & 127.9 & 20,600 & 40,500 & $2,745^{\mathrm{a}}$ & 2,583 & 500 \\
\hline Portugal & 91916 & 10,627 & 115.6 & 8,700 & 15,400 & $5,880^{\mathrm{b}}$ & 3,991 & 557 \\
\hline
\end{tabular}

Source: Dol and Haffner (2010); Pittini and Laino (2011); Statistics Denmark (2013)

Table 2 - Tenure structure of housing markets (in percentage of total dwelling stock).

\begin{tabular}{lcccccc}
\hline & Year & $\begin{array}{c}\text { Owner- } \\
\text { occupancy }\end{array}$ & $\begin{array}{c}\text { Private } \\
\text { rental }\end{array}$ & $\begin{array}{c}\text { Non-profit or } \\
\text { social rental }\end{array}$ & $\begin{array}{c}\text { Other } \\
\text { (e.g. cooperatives) }\end{array}$ & All \\
\hline Denmark & 2008 & 53 & 19 & 21 & 7 & 100 \\
\hline Portugal & 2011 & 73 & 20 & 3 & 4 & 100 \\
\hline
\end{tabular}

Source: Skifter-Andersen (2014, 103); INE (2012). 